\title{
Religiosity, the Use of Online Media, and the Youths' Prosocial Behavior in Aceh
}

\author{
Safrilsyah ${ }^{1}, \mathrm{~S} \mathrm{Akmal}^{2}$, S Mahmud ${ }^{3}$ \\ State Islamic University Ar-Raniry, Banda Aceh ${ }^{1,2,3,}$ \\ \{safrilsyah@ar-raniry.ac.id ${ }^{1}$, saiful.akmal@ar-raniry.ac.id ${ }^{2}$, salami.mahmud@ar-raniry.ac.id ${ }^{3}$ \}
}

\begin{abstract}
This study aims to look at the effect of religiosity and the use of online media on the youths' prosocial behavior in Aceh. This study involved 12 state secondary schools in the province of Aceh by using a non-proportionate sampling technique of 402 students' participants. Research data were collected using three scales, (1) religiosity using SPPIM-R from Azma (2006), (2) using online media and (3) prosocial behavior using PTM-R from Carlo (2011). Data were analyzed by using multiple regression analysis and t-test. The results of this study showed a significant positive relationship between religiosity $(\mathrm{r}=.556 ; \mathrm{p}$ $<.00)$ and social media $(\mathrm{r}=.361 ; \mathrm{p}<.00)$ with student prosocial behavior. It also demonstrates a significant influence between the main variables and student demographics on prosocial behavior $(\mathrm{R} 2=0.528$; $\mathrm{p}<0.00)$. The conclusion of the study shows that the variable of religiosity and the use of online media can influence prosocial behavior variables $(52.8 \%)$. Respondents of this study developed the average-level of religiosity, whereas women were more religious using other languages. While the average level of prosocial online media use is medium, the female student group is the more frequent users of online media compared to their male counterparts. However, respondents in this study had an averagely medium level of prosocial behavior too, the male student group was more prosocial compared to the female students.
\end{abstract}

Keywords: Religiosity, Online Media, Prosocial Behavior.

\section{Introduction}

The development of information and communication technology today has created its own challenges for Muslims, especially Muslim youth groups in Aceh. It turned out to be a negative phenomenon among the youth group and at the transitional stage age group. They are very easily influenced by individualism, hedonism, vandalism and juvenile delinquency. This occurrence can be seen from the decreasing number of inconsiderate teenagers, lack of respect, reluctance to engage voluntarily in social activities such as helping orphans, helping victims of accidents, sharing and cooperating in the society [1].

These social phenomena remain unchecked. It is highly feared that they will affect the loss of prosocial behavior among youths [2]. This prosocial behavior decline will subsequently cause various social problems, negative behavior, social damage and violation of social norms in the society [3]. Several factors, among others, that can influence prosocial behavior are religiosity and the use of media as the main focus of this article focus. At the same time, this 
article explains the significant differences in student prosocial behavior by referring to their gender.

\section{Prosocial and Religiosity Behavior}

The development of prosocial behavior is also positively related to religion because some religious values emphasize the social obligation [4], [5]. Pure values in world religion have the same goal, namely peace and non-violence, mutual help and forgiveness. Therefore experts agree that religion is an important factor in shaping the youth's prosocial behavior [6]. In the late adolescence or early adulthood group, they are at a transitional period of searching for identity and social, and thus, they have a high desire to understand the meaning of values and beliefs they hold [7].

Previous studies have suggested that the role of religiosity is important in the formation of the youth's prosocial behavior values. Devout individuals tend to live comfortably and not to commit suicide [8] do not have sexual intercourse before marriage [9] and avoid the abuse of alcohol and drugs [10]. Thus, pious students are eager to help and cooperate with their friends [11],[12]. In addition, individuals with high (religious) spirituality tend to feel they have better social skills by contributing to prosocial behavior. In the end, it is safe to say that one's spirituality can serve as a protector for him, not to engage in anti-social behavior acts.

\section{Prosocial Behavior and Online Media}

Prosocial behavior can also be influenced by online media, especially online social media. Prosocial behavior through social media itself can be done in a variety of ways, one of which is to retweet the status of other people on Twitter social media and provide constructive comments on other people's uploads is also a prosocial behavior [13].

With regard to current development, social media actually has the potential to be used as things that are beneficial to society. Social media is used as a means of giving and receiving information, making friendships, creating an inviting event, uploading videos or photos and commenting on them [14]. Nevertheless, it could also be misused [15].

Apart from being used as a media for someone to express what is thought, felt and expected, online social media can also be used as a media to communicate with others, to get an education, to shop, to play games, to search entertainment media, and to more issues ranging from business to politics. The use of social media can also be used as a perfect place for prosocial behavior [1], [16]. Among prosocial behavior examples by some online media, users are to contact people who need help via chat, voice notes, telephone, and video calls. Furthermore, it can also be uploaded into a status or story on WhatsApp, Instagram, Facebook, line, and twitter. At least prosocial behavior can be done with Like \& Retweet via Twitter and Line [17].

There have been many previous studies that have examined the effect of online media (especially video games) on prosocial behavior. Although, some studies found no significant effects on playing video games and prosocial behavior [18], [19], the majority of those studies have suggested that there is a significant effect on behavioral changes in respondents of these studies [20], [21].

There are also influences found that the use of online media, in this case, prosocial video games, on teenagers' prosocial behavior. The study from Teng et al [22] states that prosocial behavior appears to be more eager to donate some money in an experimental group after using prosocial video games. In line with the findings, Annders, et al. [23] also discusses behavior 
change and behavior correlation expected by online media in the form of video games. He concluded that prosocial video games can promote empathy or prosocial behavior for its users. The results of research by Wijaya and Godwin [24] confirmed that the use of online social media (Facebook and Twitter) had a real influence on real-life in adolescents, both for prosocial and antisocial behavior. The influence on prosocial behavior is formed when adolescents use social networking sites as a medium of friendship, exchanging information, expanding horizons, even doing online businesses that can provide sensible benefits. On the antisocial side, it is not exceptional to find quarrels that occur on social networking sites, such as the spread of radicalism, inappropriate photos / links and destructive status posts.

Nonetheless, Yee (in Syafa'atun) [25] found that 53\% of individuals who experienced online media addiction have problems in social relations because starting relationships in the virtual world is easier than in real social life. Even students who often played online games with a background or violent content may effectively trigger children to increase aggressive thoughts, feelings of anxiety, and thus, decrease prosocial behavior [26]. Too much use of online media or playing games makes children become isolated from the social environment. Apart from that, they can spend less time on other more useful activities [21]. Some parents state that the use of online media has a good influence on the children's relationships with peers and also may also stimulate a good influence on children's social activities [27].

Even in today's digital era, technology and online media have formed patterns of understanding and religiosity for urban communities, namely religiosity without religion on one side and excessive fundamentalism on the other. Consumers and producers of information, almost without barriers, are found when the concept of new media began to be applied in the form of online social media, such as Facebook, Twitter, Blogspot, and other types of social media in the form of videos such as youtube and the like that can be accessed by the general public [28]. Indirectly, online media can provide religious information and subsequently become so principal for prosocial behavior. From the description above, this study proposes the hypothesis that there is an influence of religiosity and the use of online media on the development of prosocial behavior in adolescents.

\section{Method}

This study involved 12 state secondary schools in the Aceh province with a sample of 402 students (147 men and 255 women). The sampling technique is non-proportional stratified sampling in several secondary schools located in the west, east and center of Aceh province. Research data were collected by using three scales, (1) religiosity using SPPIM-R from Azma [29] (2) online media usage and (3) prosocial behavior using PTM-R from Carlo [30]. Data were then analyzed by multiple regression analysis (multiple regression) and t-tests to see the differences between male and female respondents.

\section{Results and Discussion}

Based on the Table. 1, the findings of this study indicate that the descriptive analysis of frequency and percentage were used to describe the 402 respondents' demographic background, which included gender, residence, and type of school. Based on this description, there are 255 female respondents $(63.4 \%)$ and 147 male respondents (36.4\%) involved in the study. Furthermore, the results of the study showed that the majority of respondents, living in villages (243 respondents, equivalent to $60.4 \%$ ) and only 156 respondents (39.6\%) living in 
urban areas. In addition, the results of the study also showed that the majority of respondents were 249 secondary state public school students $(61.4 \%)$ and 153 students $(38.1 \%)$ were from the Islamic public secondary schools.

Table 1. Respondents' Demographic Outlook

\begin{tabular}{llll}
\hline Demograpy & & Frequency & Percentage \\
\hline Gender & Male & 147 & 36.4 \\
& Female & 255 & 63.4 \\
Residency & Urban/City & 156 & 39.6 \\
& Rural/Village & 243 & 60.4 \\
School & State public & 249 & 61.4 \\
& Islamic school & 153 & 38.1 \\
\hline
\end{tabular}

Based on Table.2, the findings of this study indicate that the level of religiosity of research subjects is at a moderate level of $261(64.9 \%)$ with an average value of 3.59 . Likewise, in the use of online media, 267 people $(66.4 \%)$ respondents have a moderate level with an average mean of 3.31. Meanwhile, the results of research on prosocial behavior variables show that the overall average score of the mean obtained was 3.37 with the majority of respondents were at a moderate level of 273 people $(67.9 \%)$.

Table 2.Description of Research Data Variables

\begin{tabular}{llllll}
\hline Variable & N & Mean & S.D & Minimum & Maximum \\
\hline Religiosity & 402 & 3.590 & .579 & 2.28 & 4.97 \\
The Use of Social Media & 402 & 3.305 & .446 & 2.23 & 4.31 \\
Prosocial Behavior & 402 & 3.370 & .323 & 2.44 & 4.23 \\
\hline
\end{tabular}

Table 3. Frequency of Religiosity, Online Media Use \& Prosocial Behavior

\begin{tabular}{|c|c|c|c|}
\hline Variable & Category & Frequency & Percentage \\
\hline \multirow{3}{*}{ Religiosity } & Low & 57 & 14.2 \\
\hline & Moderate & 261 & 64.9 \\
\hline & High & 84 & 20.9 \\
\hline \multirow{3}{*}{ The Use of Social Media } & Low & 80 & 19.9 \\
\hline & Moderate & 267 & 66.4 \\
\hline & High & 55 & 13.7 \\
\hline \multirow{3}{*}{ Prosocial Behavior } & Low & 66 & 16.4 \\
\hline & Moderate & 273 & 67.9 \\
\hline & High & 63 & 15.7 \\
\hline
\end{tabular}

Use of Online Media and the Appreciation of Prosocial Behaviour Core Values

Table 4. illustrates the results obtained from multiple regression analysis with the two independent variables showing that religiosity and the use of online media have a significant effect on prosocial behavior at $\mathrm{p}<0.05$ ie $\mathrm{R} 2=.521 ; \mathrm{p}<.000$. This situation explains that religiosity and the use of online media have provided as much as $52.1 \%$ change in the variance in prosocial behavior. Statistical test results on the value of the beta coefficient indicate that the variable of religiosity $(\beta=.581, p<.000)$ and the use of online media $(\beta=.370, p<.000)$ have a significant influence on student prosocial behavior. 
Table 4.The Effect of Religiosity Dimension toward Prosocial Behavior

\begin{tabular}{lll}
\hline Variable & B & Sig. \\
\hline Religiosity & .581 & .000 \\
The use of online media & .370 & .000 \\
Value R & .722 & .000 \\
Value R $\mathrm{R}^{2}$ & .521 & \\
Value F & 216.930 & \\
\hline$P<.05$ & &
\end{tabular}

The results of the regression analysis showed that religiosity and online media use significantly contributed as much as $52.1 \%$ to prosocial behavior where $\mathrm{p}=.000<.05$. In other words, the prosocial behavior of students is influenced by the level of religiosity and online media usage by $52.1 \%$, and there are $47.9 \%$ influenced by other factors; such as peers, parents and social activities.

\section{Effect of Main and Demographic Variables on Prosocial Behavior}

Multiple regression analysis with the stepwise method has been used to determine the specific contribution of independent variables to student prosocial behavior. The stepwise method selectively incorporates independent variables that contribute significantly to the independent variables in the regression model. Before the analysis, it was assumed that all the independent variables, namely the religiosity of online media usage, were confirmed on a Likert scale. When various independent variables (gender, place of residence, type of school, father's education level and mother's education) are categorical variables, then these variables have been used as dummy variables, gender (male $=1$, female $=2)$, place of residence $($ City $=$ 1 , Village $=2$ ), type of school (general high school / high school $=1$, religious high school $/$ $\mathrm{MA}=2$ ). Next, all variables were also tested for multivariate analysis before being analyzed. Apparently speaking, multicollinearity, normality, linearity, homoscedasticity of residual and multivariate remote points have been examined through various SPSS programs.

The multiple regression analysis by using the stepwise method in table 5 shows a regression model in which students' prosocial behavior as the dependent variable while religiosity, the use of online media and maternal education as independent variables, yields a significant model $(\mathrm{F}=48,968), \mathrm{p}=0,000)$. Thus, the factors of religiosity, the use of online media and mother's education considerably contribute to the prosocial behavior of students as much as $\mathrm{R} 2=.529$. This shows as much as $52.9 \%$ of the variance in prosocial behavior explained by the variables of religiosity, the use of online media and maternal education. Furthermore, religiosity, the use of online media and mother's education have a positive relationship with student prosocial behavior. This means, religiosity, the use of online media and gender will increase the prosocial behavior of Acehnese students. In other words, a pious student uses the internet wisely and students with parents (especially mothers) in influencing their high prosocial behavior too. The regression model can be seen below:

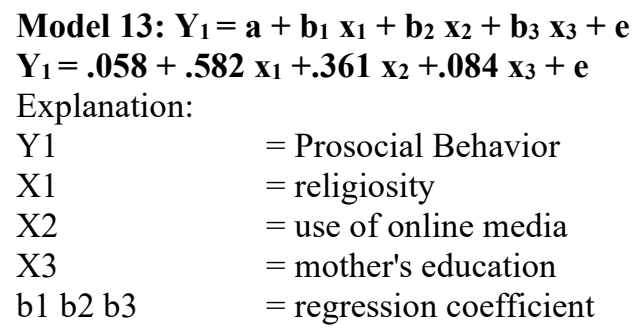




$$
\begin{array}{ll}
\mathrm{a} & =\text { constant } \\
\mathrm{e} & =\text { error }
\end{array}
$$

The results of the multiple regression test by using the stepwise method show that there are only three variables, namely religiosity, the use of online media and mother's education which can influence the prosocial behavior of Acehnese students. The analysis also shows that the variables of religiosity, the use of online media and mother's education have a significant positive relationship with prosocial behavior for students. Meanwhile, the R2 value obtained indicates the combination of the three independent variables, namely religiosity, the use of online media and mother's education can explain $52.9 \%$ of variance over student prosocial behavior (see table.5). This means that there are $47.1 \%$ of the variance in prosocial behavior of Acehnese students explained by other variables (such as government policies, information technology, newspapers/magazines, family parenting, teachers at school and peers).

Table 5. Analysis of Multiple Regression of Independent Variables in Prosocial Behavior.

\begin{tabular}{lllll} 
Variable & Beta $(\boldsymbol{\beta})$ & $\mathbf{R}^{2}$ & F & Sig. \\
\hline Constanta & .058 & .529 & 48,968 & .000 \\
Religiosity & .582 & & & \\
The use of online media & .361 & & & \\
Mother's education & .084 & & & \\
\hline$P<.05$ & & &
\end{tabular}

Differences in Religiosity, Use of Online Media and Prosocial Behavior of Students by Gender

Table 6 below shows that there is no difference in student religiosity by gender factor $(\mathrm{t}=$ $.81 ; \mathrm{p}=.06>.05$. There is no difference in the use of student online media based on gender factor $(\mathrm{t}=1.15 ; \mathrm{p}=.62>.05)$. Then, there is no difference in student prosocial behavior based on gender $(\mathrm{t}=1.16 ; \mathrm{p}=.92>.05)$. However, based on the average value, the level of religiosity of male students is higher than female students, and the average value of prosocial behavior of male students is higher than female students and the average value of the use of online media male students are higher than female students.

\begin{tabular}{|c|c|c|c|c|c|}
\hline & Gender & $\mathbf{N}$ & Mean Rank & $\mathbf{t}$ & Sig. \\
\hline \multirow[t]{3}{*}{ Religiosity } & Male & 255 & 3.60 & & \\
\hline & Female & 147 & 3.55 & & \\
\hline & Total & 402 & & .81 & .06 \\
\hline \multirow[t]{3}{*}{ The Use of Online Media } & Male & 255 & 3.32 & & \\
\hline & Female & 147 & 3.27 & & \\
\hline & Total & 402 & & 1.15 & .62 \\
\hline \multirow[t]{3}{*}{ Prosocial Behavior } & Male & 255 & 3.39 & & \\
\hline & Female & 147 & 3.33 & & \\
\hline & Total & 402 & & 1.66 & .92 \\
\hline
\end{tabular}

Table 6. Differences in Prosocial Behavior Based on Gender

The results found that religiosity and the use of social media had a significant influence on the prosocial behavior of secondary school students in Aceh. By combining the overall factors that contributed to the influence of prosocial behavior as much as $36.7 \%$ change in the variance of prosocial behavior, this result implies that prosocial behavior is influenced by 
student religiosity by $52.9 \%$. The remaining $47.1 \%$ is influenced by other factors, such as government policies, information technology, newspaper magazines, family parenting, school teachers and peers. This achievement confirms that piety is very important to awakening the youth's prosocial behavior. This is because most of the education and the teaching of Islamic Sharia in Aceh is more focused on the field of worship and sharia in Islamic fiqh compared to other focuses such as on monotheism and aqeedah [31]. This achievement also supports previous studies which state that students' prosocial behavior is influenced by religiosity [32], [33]. Furthermore, this statement clearly proves that religiosity makes an important contribution in determining the development of prosocial behavior such as helping, sharing with others in need. This achievement supports Ahmed [34] statement which emphasizes that in an effort to bring about prosocial behavior and mutual cooperation within a group of students, it is necessary to be informed and to learn about the benefits of charity, sharing and helping others as manifested in the teachings of Islam.

Referring to the Islamic scholarship, the religious value possessed by Muslim youth will enable them to activate their muqarabah (self-control) and muhasabah (self-regulation) which will make them to be more sociable, to increase morality, nobleness and have Islamic habits individually and able to apply it in their communities [35]. They are able to control themselves with the freedom they have and stay away from excessive attitudes and do not follow their individual passions. They are also willing to apply the value of Islam and become a true Muslim. In addition, students can also have feelings of responsibility and compassion among humans, tolerant, respectful to the rights of others and their beliefs.

The results of a study on the influence of the use of online media on social behavior emphasize that the development of information technology, especially online social media, will have an impact on the youth if used wisely and intelligently[13], [19], [36] where it is used as a means of giving and receiving information, making friendships, posting posts, inviting events, uploading videos or photos and commenting on them.

In addition, the results of this study also explained that the role of maternal education in fostering prosocial behavior becomes even more important. A well-educated mother will simply direct her children in the use of online media in a positive direction. Educated mothers are getting accustomed to following the development of information technology in the current digital era. The quick and accurate information can help mothers in guiding teenagers in the use of internet media, instilling religious values and social norms so that it can help the formation of the youth's prosocial behavior. Furthermore, this study also found that there were no significant differences in prosocial behavior of students in public schools and religious schools. However, this study found that female students were more prosocial and more religious than their male counterparts.

\section{Conclusions}

Based on the results of the study, religiosity, the use of social media, and mother's education have a significant influence on prosocial behavior with a level of $\mathrm{p}<0.05$ ie R2 = $.529 ; \mathrm{p}<.000$. This result implies that prosocial behavior is influenced by religiosity, the use of social media, and maternal education by $52.9 \%$, whilst $47.1 \%$ prosocial behavior is influenced by other factors, such as peer groups, teachers at school, family parenting, personality or social activities.

The study recommends that parents, educators and the government need to prepare the youths with the provision of good religious values. A true and good understanding of religion will be the principal value that guides them to filter the information obtained and use online 
media wisely. The value of religiosity and the wise use of online media will guide teenagers to behave prosocially in the community.

The role of parents and educators in schools is very important to maintain students to always be able to work well and in accordance with the norms of applicable Islamic law. As a school educator, to emphasize the role of religiosity can simply mean to develop student behavior. The reason is that religiosity is the main core value for students to create high prosocial behavior, to be always ready to compete in a healthy way and to achieve success. In addition to this, one of the characteristics of public schools in Aceh is the introduction to the basic Islamic values, with inherent religiosity, will be more focused in the future to synchronize the Muslim youth in Aceh.

The Aceh Islamic Schools can be a model for other Indonesian schools who want to be based on Islamic principles. Also, students must be able to learn and help others as part of their religious belief, with a sense of sincerity, and responsibility. Last but not least, the government, parents, and especially educators, must be able to inspire the value of religiosity to all students by modeling (qudwah) and regularly supervising their students to always attend lectures and recitation of the Holy Koran every Friday morning in schools and other places of worships.

\section{References}

[1] C. Juditha, "Hubungan Penggunaan Situs Jejaring Sosial Facebook Terhadap Perilaku Remaja Di Kota Makassar," J. Penelit. IPTEK-KOM, vol. 1, no. 2, pp. 1-23, 2011.

[2] S. Amelia D. and A. D, "Kecenderungan Kenakalan Remaja Ditinjau Dari Kekuatan Karakter Dan Persepsi Komunikasi Empatik Orangtua," J. Psikol. Integr., vol. 5, no. 1, pp. 47-68, 2017.

[3] Sigit H and S. R. Elfi, "Remaja dan Perilaku Menyimpang (studi kasus remaja kota Padangsidimpuan)," J. Interak., vol. 2, no. 1, pp. 23-32, 2018.

[4] A. Abdel-Khalek, "Personality dimensions and religiosity Among Kuwaiti Muslim college students," Pers. Individ. Dif., vol. 54, no. 2, pp. 149-152, 2013.

[5] G. Carlo, L. Crockett, J. Wilkinson, and S. Beal, "The longitudinal relationships between rural adolescents' prosocial behaviors and young adult substance use," $J$. Youth Adolesc., vol. 40, no. 9, pp. 1192-1202, 2011.

[6] H. Hanafi, Agama, Kekerasan dan Islam Kontemporer. Yogyakarta: Lentera, 2010.

[7] A. Jamaludin, Psikologi Islami. Yogyakarta: Pustaka Pelajar, 2010.

[8] M. McCullough and Willoughby, "Religion, self-regulation, selfcontrol: Associations, explanations, and implications," Psychol. Bull., vol. 135, no. 2, pp. 69-93, 2009.

[9] D. McCree, R. Wingood, GM, DiClemente, S. Davies, and Harrington, "Religiosity And Risky Sexual Behavior In Adolescent Females African- American," J. Adolesc. Heal., vol. 33, no. 1, pp. 2-8, 2003.

[10] J. Palamar, M. Kiang, and P. Halkitis, "Religiosity and Exposure to Users in Explaining Illicit Drug Use Among Emerging Adults," J. Relig. Health, vol. 23, no. 4, pp. 1-17, 2012.

[11] A. Ahmed, "Are religious people more prosocial? A quasi-experimental study with madrasah pupils in a rural community in India," J. Sci. Study Relig., vol. 48, no. 2, pp. 368-374, 2009.

[12] V. Ahmadi, I. Davoudi, M. Mardani, M. Ghazaei, and B. ZareZadegan, "The relationships Among moral development, religiosity and religious orientation in 
students," Procedia Soc. Behav. Sci., vol. 84, no. 2, pp. 674-678, 2013.

[13] G. Puspita, S. D., \& Gumelar, "Pengaruh Empati Terhadap Perilaku Prososial Dalam Berbagi Ulang Informasi Atau Retweet Kegiatan Sosial Di Jejaring Sosial Twitter," J. Penelit. dan Pengukuran Psikol., vol. 3, no. 2, pp. 1-7, 2014.

[14] P. Briggs, A.danBurke, Sejarah Sosial Media: dari Gutenderg sampai Internet. Jakarta: Yayasan Obor Indonesia, 2000.

[15] R. . Wimmer and J. . Dominick, Mass Media Research : An Introduction. New York: Wadsworth, 2011.

[16] P. Felita, "Pemakaian Media Sosial Dan Self Concept Pada Remaja," J. Ilm. Psikol. Manasa, vol. 2, no. 1, pp. 30-41, 2016.

[17] A. A. D. Nugraha, "Prilaku Prososial Melalui Media Sosial," in Skripsi, 2018.

[18] J. M. Jerabeck and C. J. Ferguson, "The Influence Of Solitary And Cooperative Violent Video Game Play On Aggressive And Prosocial Behavior," Comput. Human Behav., vol. 29, no. 6, pp. 2573-2578, 2013.

[19] M. J. Tear and M. Nielsen, "Failure To Demonstrate That Playing Violent Video Games Diminishes Prosocial Behavior," PLoSOne, vol. 8, no. 7, pp. 168-18, 2013.

[20] D. A. Gentile et al., "The Effects Of Prosocial Video Games On Prosocial Behaviors: International Evidence From Correlational, Longitudinal, And Experimental Studies," Personal. Soc. Psychol. Bull.

[21] T. Greitemeyer and C. Cox, “There's No'I'In Team : Effects Of Cooperative Video Games On Cooperative Behaviour,” Eur. J. Soc. Psychol., vol. 43, no. 3, pp. 224-228, 2013.

[22] Z. Teng, Q. Nie, Y. Liu, and C. Guo, "Is Prosocial Video Game Exposure Related To Prosociality? An ERP Study Based On A Prosocial Help Needed Decision Task," Comput. Human Behav., 2017, doi: doi: 10.1016/j.chb.2017.10.014.

[23] C. A. Anderson et al., "Violent Video Game Effects On Aggression,Empathy,And Prosocial Behavior In Eastern And Western Countries: A Meta-Analytic Review," Psychol. Bull., vol. 136, no. 2, pp. 151-173, 2010.

[24] C. Wijaya and R. Godwin, "Hubungan Perilaku Sosial Dalam Beraktivitas Di Situs Jejaring Sosial Dan Dunia Nyata Pada Remaja Di Jakarta,” J. Universtas Bina Nusant., vol. 2, no. 3, pp. 26-44, 2012.

[25] N. Syafa'atun, “Tumbuh Kembang Anak Di Era Digital,” J. Pendidik. dan Stud. Islam, vol. 4, no. 1, pp. 72-84, 2017, doi: DOI 10.5281/zenodo.1227474.

[26] T. Greitemeyer and D. O. Mügge, "Video Games Do Affect Social Outcomes: A Meta-Analytic Review Of The Effects Of Violent And Prosocial Video Game Play," Personal. Soc. Psychol. Bull., vol. 40, no. 5, pp. 578-589, 2014.

[27] W. S. Gilang, A. Muhammad, S. Mawaddatus, L. G. Shepty, R. Tyas, and Fitroh, "Pengaruh Teknologi Informasi Terhadap Kecerdasan (Intelektual, Spiritual, Emosional Dan Sosial) Studi Kasus: Anak-Anak, Studia Informatika,” J. Sist. Inf., vol. 10, no. 2, 2017.

[28] A. Aziz, "Religiusitas Masyarakat Urban di Era Digital (The Religiosity of Urban Communities in the Digital Era)," in Conference paper, 2018.

[29] A. Mahmood, "Pengukuran tahap penghayatan pendidikan Islampelajar-pelajar sekolah menengah di Malaysia," Universit iKebangsaan Malaysia Bangi, 2006.

[30] G. Carlo, M. Mestre, P. Samper, A. Tours, and B. Armenta, "The Longitudinal Relations Among Dimensions Of Parenting Styles, Sympathy, Prosocial Moral Reasoning, And Prosocial Behaviors," Int. J. Behav. Dev., vol. 35, no. 2, pp. 116-124, 2011. 
[31] F. Saleh, Konsep Sulh dan Konsturuksi Pendidikan Damai di IAIN Ar-Raniry”, dalam Nasir Budiman (ed.) Pergulatan Panjang Budaya Damai dalam Masyarakat Multi Kultural. Banda Aceh: Ar-Raniry Press, 2007.

[32] K. K. Clobert, M., Saroglou, V., \& Hwang, "Buddhist Concepts As Implicitly Reducing Prejudice And Increasing Prosociality," Personal. Soc. Psychol. Bull., vol. 41, no. 2, pp. 513-525, 2015, doi: http://dx.doi.org/10.1177/ 0146167215571094.

[33] \& T. Guo, Liu, "Religiosity and Prosocial Behavior at National Level", Psychology of Religion and Spirituality," Am. Psychol. Assoc., vol. 10, no. 99, 2018, doi: http://dx.doi.org/10.1037/rel0000171.

[34] O. Ahmed, A., \& Salas, "Religious Context And Prosociality: An Experimental Study From Valparaiso, Chile,” J. Sci. Study Relig., vol. 52, no. 2, pp. 627-637, 2013, doi: http://dx.doi.org/10.1111/jssr.12045.

[35] Al-Ghazali, Akhlak seorang Muslim. Kuala Lumpur: Victoria Agencies, 1992.

[36] Selviana, "Empati Dan Penggunaan Situs Jejaring Sosial Sebagai Faktor Dalam Membentuk Moral Remaja," J. Psikol. Ulayat, vol. 3, no. 3, pp. 143-157, 2016. 